Nicoletta Cabassi

University of Parma

nicoletta.cabassi@unipr.it

ORCID: 0000-0001-9513-4850
Data przysłania tekstu do redakcji:10.11.2019

Data przyjęcia tekstu do druku: 09.01.2020

\title{
Futurist Suggestions in the War Poems by Josip (Sibe) Miličić
}

Abstract: Cabassi Nicoletta, Futurist Suggestions in the War Poems by Josip (Sibe) Miličić, "Poznańskie Studia Slawistyczne" 18. Poznań 2020. Publishing House of the Poznań Society for the Arts and Sciences, Adam Mickiewicz University. pp. 67-82. ISSN 2084-3011.

With the opening of the twentieth century, the beneficial river of the avant-gardes seemed to flood the entire European continent in a happy contamination of national cultures, giving life to an authentic supranational koine of artists: it was sometimes fusion of forms, styles, environments, cultures, a salutary effort to rejuvenate languages. The particular attention of the Italian Futurists to the new national realities was among the factors of particular attraction to the movement for South Slavs whose representative was Josip (Sibe) Miličić, who called for cultural and political renewal of his country. His direct encounter with Marinetti and Boccioni seems to leave its mark on his poetry both structurally and thematically: in the collection from 1914, Miličić reveals a new sensibility and a new rhythm: in one of his war lyrics, the futurist suggestions materialize in his first onomatopoeic attempt, suitable to undermine the lyricism of the verse by intensifying the link between the phonic aspect and the meaning. Despite their common interventionism, the Great War found the Croat and the Italian Futurists on opposite political positions concerning the Dalmatian islands and the Italian expansionism on the Adriatic. The poet's war experience lead him to a "mature" phase starting in the twenties with his first article-manifesto. At this time he was able to reprocess his own critical identity: affirming his deeply anti-materialist and anti-industrial spiritualism, his standpoints by then had become very distant from Marinetti's insights.

KEYwords: Italian Futurism; South Slavs; Great War; war lyrics

The intense activity of spreading the Italian Futurist movement, together with the great communication skills of its undisputed leading actor, Filippo Tommaso Marinetti, widened the potential of permeation of the movement in various national realities. Marinetti, man of international vocation, since his beginnings was concerned with the dissemination of his manifestos and publications abroad along with his visits to many places in Europe: among his propaganda tours, in which he used to give lectures, attend exhibitions or Futurist theatrical performances, we remind here those 
in Russia, Czechoslovakia, Romania, Bulgaria and Poland. It was an out-of-the-ordinary opening to Europe, in particular to Eastern Europe where, since the 1910s, his Futurist manifestos and texts were read and translated, and a substantial corpus of information materials circulated (Tomassucci, Tria, 2009, 5). The attention to the new national realities, in addition to the great communicative potential, was among the factors of particular attraction for the intellectuals of those countries aspiring to the cultural and political renewal of their countries.

Croatia also closely followed the Italian movement: we find the first echoes not far from the first Marinettian Manifesto, on the journal "Savremenik" (Contemporary), in Zagreb: already in the third issue of 1909, in fact, an article entitled Futurizam (The Futurism) was published, followed by the proclamation of Marinetti himself (Petrač, 1995, 8); in the same year his Proclaim also appeared in Slovenia, on the "Ljubljanski Zvon" (Ljubljana's Bell). Two years later, Sibe Miličić's article on "Bosanska Vila" came out, and another one was written on the same subject by Zdenka Marjanović: in both cases, these were impressions written from Rome (Miličić) and Milan (Marjanović) on the meetings with the main heroes of Italian Futurism. Only in 1913 a real programmatic article by Dimitrije Mitrinović, Estetičke kontemplacije (Aesthetic contemplation) will be released on the same journal. Also it is not to be forgotten the fact that in 1914 the first unsuccessful attempt was made to create the first Croatian Futurist magazine in Zadar, "Zvrk" (Whirligig, Zani, 1985, 303-349): other Croatian countrymen such as Anton Aralica in 1913 lived in Italy and approached the Futurists by taking part in their meetings and by collaborating with Marinetti (Petrač, 1995, 20).

Particular consideration will be given here to a Croatian by birth, Josip Sibe Miličić, ${ }^{1}$ a proponent of the Yugoslavian cause, portrayed in his

\footnotetext{
${ }^{1}$ Born of a Croatian mother, he completed his studies in Slavic and Roman philology in Vienna, and continued his eclectic training in the visual arts and painting in Florence, Rome and Paris. He was a collaborator of some journals like the Corfiot "Zabavnik," but also "Bosanska Vila," "Srpske Novine," and "Misao." His first poetic attempts (Pjesme [Poems], 1907, Deset Pjesama o Don Juаnu [Ten Poems on Don Juan], 1912) found him engaged in themes and forms dear to the Croatian modernists, while with the third collection, 3, Treća knjiga pjesama (The Third Book of Poems, 1914), edited in Vienna at the outbreak of the First World War, Miličić had already revealed "Cosmic" inclinations. The post-war compositions, Knjiga Radosti (The Book of Joy, 1920), Knjiga Vječnosti (The Book of Eternity, 1922),
} 
Futurist period (Brusje 1886 - Bari 1945): poet, painter, writer, critic, he was an eclectic and manifold talent who evolved and grew artistically in such great capitals like Wien, where he graduated, Belgrade, Rome, Paris, cities overwhelmed by the avant-gardes, spreading new horizons and renewing languages, in contrast to the prevailing communicative models.

Miličić shared a close relation with the avant-garde arts and the Symbolist heritage investing the entire European continent: as a matter of fact, his formation appears to be inseparable from that great container and generator that was decadence and Symbolism: the very priority to poetry over prose was, after all, great Symbolist legacy, as well as the initial use of vers libre. The first poetic attempt, Pjesme, (Poems, 1907) saw him engaged in themes and structures near the Decadents (Milanja, 2000, 138): melancholy - pessimistic anxieties, ashen and rainy landscapes, nostalgic memories of native places, metaphors (Lešić, 1991, 27) in rhymed quatrains. ${ }^{2}$

Examining the events and circumstances leading Miličić to make direct acquaintance with the Italian Futurists, the writer, enrolled at the University of Wien in the academic year 1905-1906, went to Italy between 1907 and 1908. He travelled mainly to Florence and Rome (Ćošić, 1931, 49): there is neither sources nor evidence referring to Miličić's artistic and literary contacts during his staying. In the same years, Marinetti shuttled back and forth Paris and Milan (Agnese, 1990, 104-106), while in 1907, while Umberto Boccioni moved from Padua to Venice to enrol in the School of the Nude of the Institute of Fine Arts and to

\footnotetext{
gave him an important role in representing the Croatian Expressionist-Cosmic lyric (about his Cosmic poetry interpreted as a kind of abstract Expressionism, v. Vučković, 2011, 140). Primarily from the figurative arts, in particular from painting, he transposed the expressive ontology and semantic repertoire he would have deployed in The Book of Joy, a sort of manifesto in which his poetry, with its spirituality, would have become the new religion. The last poetic collection, Deset partizanskih pesama (Ten Partisan Poems, 1944), in spirit and images are far from the years of Cosmism. He died in a Bari-Bar night crossing, presumably committed suicide.

${ }^{2}$ The refined graphics of the drawing edited by the "secessionist" Tomislav Krizman who finished his studies at the Academy of Fine Arts in Vienna in 1907, and had his artistic debut in the collection of his friend; Krizman had grown in a climate where the idea of a total art, of a renewal flow tracing rich connections between poetry and painting, illustration and narrative was characterized by great influence. In this collection, Miličić also paid tribute to Giosuè Carducci who died right in that year; he managed to translate three poems from Carducci's most important work, Le rime nuove (New Rhymes, 1887).
} 


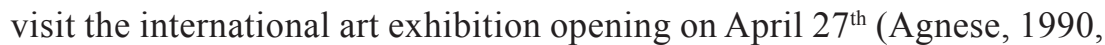
136). We can only assume that even the twenty-year-old Croatian artist, in search of formative experiences and new horizons, has undergone the international appeal of this great event and visited this exhibition where it was possible to view the best of European art. He also started collaborating with some literary journals and magazines publishing his poems. For the types of the Croatian Academy Jadran, in 1911 he published the second collection of lyrics under the pseudonym of Josip Griješni (Josip the Sinner), over which we will not linger in this paper. In the same year, for the journal "Bosanska Vila" (The Bosnian Fairy), Miličić finally described an important meeting with the animators of Futurism during one of their famous séances: the article, entitled Pismo iz Italije (Letter from Italy), came out in autumn 1911 (no 11/12), when Miličić wrote about himself as being "in the heart of Rome," at the Caffè Aragno. It should be considered, however, that from October until mid-November 1911, the Futurist movement had suspended all the activities in relation to the absence of the poet Marinetti, who had left as special correspondent for Libya (Agnese, 1990, 114-118): while Marinetti was on his mission, all the other Italian Futurists took the chance to go to France to see what was going on in Paris (Agnese, 1990, 238). It is, therefore, possible that Miličić might have published this article not simultaneously with the meeting, but on a delayed terms, some time later: ${ }^{3}$ in identifying the precise period it could help the fact that, still in 1911, Zdenka Marjanović wrote about Miličić ${ }^{4}$ taking part in a "famous Boccioni's conference" ("Bosanska Vila," 1911, 13/14): maybe she refers to the most famous performance, on May 29 $9^{\text {th }} 1911$, when Boccioni, well-known as the spearhead of the Italian Futurists, had spoken about the perspectives of Futurist art (Agnese, 1990, 222). A further element supporting the proposed

\footnotetext{
${ }^{3}$ In this sense, I diverge from the hypothesis made by Lešić referring to the meeting with Marinetti in the autumn 1911 (Lešić, 1991, 32).

${ }^{4}$ Marjanović - like Miličić - witness to this Futurist performance and conversationalist with Marinetti, offers a more general informative article in the next issue of the journal describing in detail the proclamations, developments and the political events of the Italian movement: more critical on the Futurists (the Futurist explosion is an "explosion of desperation power," Marjanović, 1911, 212), the reporter paid attention to the soul as one of the many moments proclaimed by the Futurists, without lingering or emphasizing as Miličić does.
} 
periodization could be the fact that the poet from Brusje, from September $19^{\text {th }} 1911$ took service as a substitute teacher at the local Gymnasium in Dubrovnik, where he stayed for one year (Lešić, 1991, 34).

But one should take, however, a closer look at the encounter taking place "u malenoj, poznatoj sobici, gdje se sastaju svi literatuni, literati i literatici" (in a small well known room where all the writers, the great and the small ones, are gathering) and where they spoke "of everything and anything" (Miličić, 1911a, 180). As a correspondent, Miličić interviewed the two Italian Futurists: in his report, he summarized some of the most famous positions in Marinetti's manifesto: in particular, the tenth proclamation, the idea of breaking with the past ${ }^{5}$ seemed to strike him "I hoćemo da izbacimo sve što su naši dobri djedi ostavili u nasleđe" (And we want to throw away all what our good grandfathers left us behind, Miličić, 1911a, 180). The fact of feeling "different" from their predecessors, a restless generation ("mi smo nervozni u tjelu"), not recognizing any aesthetic and moral dogma used by those who preceded them, and therefore wanting to abandon "the beautiful form, the beautiful word," fully confirm what was already argued by Predrag Palavestra: behind these attempts to open up to Futurism, there was an unsatisfied and uneasy Croatian and Serbian literary and intellectual youth, seeking new ideas, new standards and new values (Palavestra, 1979, 249). The joy and enthusiasm of these new sensibilities and proposals ware counterpointed by a great pain and nostalgia, thinking about how distant and still unprepared was his country: fascinated by the idea of breaking with the past, persuaded by the need of changing the epistemological paradigm for a new human being (Milanja, 2000, 14), Miličić did not lean, however, towards the anti-passatist and destructive inclination of Italian Futurism (Lešić, 1991, 33).

The reporter also exposed he had listened to the lecture held by "that young Futurist painter" a couple of hours earlier: a very turbulent session, where Boccioni "nazvao je svoje slušaoce [...] glupanima [...] so psovkama i porugom" (called his listeners [...] stupid [...] with deriding and mockery"; Miličić, 1911a, 180). Their tumultuous sessions were well

\footnotetext{
${ }^{5}$ Marinetti, as it is well known, invited to destroy libraries and museums, and to forget the geniuses of the past because "too many reminiscences separate man from reality" and, therefore, the knowledge of the past prevented from "the immediacy of perception, the freshness of joys" (De Michelis, 2009, 60).
} 
known to end in fights: even here, Miličić, aware of some proclamations of Boccioni's manifesto for the painting (April 11 ${ }^{\text {th }} 1910$ ), addressed to the beauty and the essence of Futurism, "Let's give our souls to the art [...] let's fly, let's run ahead, ahead [...] closer to the soul! [...] to the realm of the soul" (Miličić, 1911a, 181). Tuning with Boccioni, Miličić specified that the purpose of the artwork in futurism searching was to show the simultaneity of moods (Agnese, 1990, 251): for that reason, to these artists recorded the Croat - the drawing by a child or a madman was worth more than by the greatest genius, because in the first we find the "pure soul" (Miličić, 1911a, 181): the hinting at the child's "nude soul" (gola duša) and the returning to the innocence of childhood will allow us to perceive full and deep maturity in the mystique of the Croatian author - mad and naive child from The Book of Joy (Knjiga radosti,1920), who aims to be all one with nature and with the world.

Miličićs admired words for the "poetics of the soul" met the romanticimpressionist tendency being developed within Futurism (especially in its Russian version): the soul was attracted by the primordial, the primitive, the elementary, a "primitivism" which turned out to be superficial and external for the aesthete Marinetti, while for Miličić (as in the Russian Futurists) it involved a much more intimate and deeper approach, consciously revealed $^{6}$ in the next collection of lyrics (1914). ${ }^{7}$

The last part the speech of the article becomes more "political" and more emotionally involved, since it relies not so much on the contents of the futurist movement, as on an explicit appeal to his homeland: the stimmung marked by enthusiasm and the exaltation is now completely damped in the discomforted considering his country artistic conscience. Miličić not only embraces the Marinettian proposal to give a voice to artists and writers in a supranational dimension, as a support and stimulus to their own national reality, but he's already the spokesperson for that Yugonational ideal

${ }^{6}$ The avant-gardes legacy leading to Primitivism is undeniable, although it must be pointed out that the Miličićan Primitivism was something different from that of other movements, such as Futurism: it must be rather placed within the Expressionism, to which Miličić's poetry belong (Milanja, 2000, 140), less inclined to technical effect and more oriented to emphasize man's panic bond with nature.

${ }^{7}$ In the collection 3, the poet shared the aspiration to child's innocence, feeling and perception (Miličić, 1914c, 4). 
characterizing his political activism. Furthermore, Miličić at this stage was enthusiastic about the "political" appealing of the Futurists to a national revival supporting the war, invoking in particular, the struggle against Austria. The Great War was even considered by the Futurists as an aesthetic criterion: in his first manifesto, in fact, Marinetti underlined how the task of modern poetry was to sing the wonders of production, technique and of war, the only hygiene in the world (Marinetti, 1909).

Already in 1908, during Miličić's staying in Italy, there was a student and intellectual mobilization after the annexation of Bosnia Herzegovina by the Austrian Empire: it was a moment of great irredentist effervescence, regarded as an authentic opening of the Italian nationalist movement (D'Orsi, 2009, 81). Youth exaltation of war, on one hand, and antiAustrian hatred on the other, are elements naturally leading the Futurists to support the cause of the intervention in the Great War. In 1912 Miličić was forced to leave Dubrovnik and move to Belgrade ${ }^{8}$ right because of his active and open participation in the anti-Austrian demonstrations; supporting the Yugoslavian cause, he could not but approve the enemies of Austria, precisely, the Italian Futurists.

During that summer, the Balkan League was preparing an ambitious project by joining Bulgarians, Serbs, Montenegrins and Greeks: expelling Turks from the peninsula and driving them back over the Bosphorus. Marinetti was in Bulgaria, in Sofia, where he recited poems exalting the Futurism and making a crowd of admirers (Agnese, 1990, 119). At the outbreak of the first Balkan war (October 1912 - May 1913), the Italian Futurist took part in the siege of Adrianople, where the Bulgarian army and two Serbian divisions, more than 150,000 men, were preparing a long offensive (from mid-November to March 1912): in the blazing of the siege, Marinetti was filling his notebook with "words in freedom": the pages of Zang Tumb Tuum on the bombing of Adrianople (Agnese, 1990, 121). Marinetti and his Futurist entourage, therefore, supporters of the Serbo-Bulgarian and Greek league against the Ottoman enemy, were ideally in harmony with Miličić, who was in Belgrade, also excited about the Balkan war and,

${ }^{8}$ In Belgrade he worked as a gymnasium teacher and had the opportunity to join literary circles and to get acquainted with personalities such as Jovan Dučić and Jovan Skerlić (Lešić, 1991, 34). 
above all, about the Serbian victory at Kumanovo (23-24 October 1912), longing for the idea of the union of the southern Slavs in a single State.

Of the Miličićan war lyric production, ${ }^{9}$ we will linger in particular on the most Futurist of his lyrics, Polazak ratnika (The warriors' departure): written in ekavic and published on "Bosanska Vila" in the Spring 1914, in memory of the Balkan wars (1912-1913), while the author was in Belgrade. In the lyric, the link between phonic aspect and meaning seems to become closer and more intense, hence, in a certain sense, the language appears to be more "revolutionary" and "futuristic." The image emerges impressionistically from the first verses praising the train on which the Serbian soldiers are leaving, described in the Futurist manner, "Fijuče zverka gvozdena, zasopljena" (Whistle the iron panting beast, Miličić, 1914a, 13): in the verb is enclosed here its first onomatopoeic attempt to make the image more real, while reproducing its noise and its movement. The image of the iron beast is repeated as a refrain with variations also reproducing the crescendo of the rhythm of the train, hissing, whistling, picking up speed, passing by the fields and near fields and meadows, near beautiful vineyards, woods and plantations ("mimo polja u livade, mimo lepe vinograde, mime šume i nasade," Miličić, 1914a, 13). The most involved sense is not the sight (very few verbs of sighting), but the hearing: many of the repeated and varied verbs, trembling, howling, calling, screaming, saying (fijuče, strepi, drhće, zove, kliču, reći) continuously solicit the ear through onomatopoeic assonances or through the "impressionistic" reproduction of the mechanical noise of the moving train.

In the Manifesto of Futurism Marinetti had already appealed to the singing of "the locomotives with their the broad chest, pawing the rails, like enormous steel horses harnessed in pipes" (Marinetti, 1909), then returning again in 1912 with the representation of "colossal trains crowded with soldiers, baggage and dynamite" (Marinetti, 1912), and another of his masters, Walt Whitman, had already exalted the powerful locomotive (1876). The locomotive takes here a sound value: the verses lose their verbal connotation and become universal sounds: through onomatopoeic

${ }^{9}$ We refer here to the production preceding the Great War, published in poems scattered between 1911 and 1914, in addition to the above-mentioned Polazak ratnika, and also Povratak pobjednika (The Return of the Winner), and Odačbina (Homeland). 
repetition and their isolation from the syntactic context, the angry beast (besna zverka) acquires a strong rhythmic effect and very elementary and immediate expressive modes.

Putuje besna zverka,

Tika taka-tika-taka, tika-taka.

Tik-tik-tik

(Goes the angry beast,

Tika taka-tika-taka, tika-taka

Tik-tik-tik, Miličić 1914a, 14).

The onomatopoeia was undoubtedly one of the most innovative aspects of Futurism, enhanced both by its marked dynamism and its conciseness, and by its internal bond with the matter and civilization (Tomassucci, Tria, 2009, 106): to this figure of speech is ascribed the task of transferring the reality of the phenomena intact and with the maximum speed, producing very rapid, brutal and immediate lyricism, "which must looks like antipoetic to our predecessors" (Marinetti, 1913). The onomatopoeia used by Miličić for the first time could be described as an elementary, direct, realistic one, according to Marinetti's description in his Manifesto on March $18^{\text {th }}$ 1914: "which serves to enrich the realism with brutal reality and to prevent from becoming too abstract or too artistic" (Marinetti 1914). ${ }^{10}$

${ }^{10}$ In the Manifesto entitled Geometric and mechanical splendour and numerical sensitivity (March 18th, 1914), Marinetti wrote: "Our growing love for the material, the will to penetrate and to know the vibrations, the nice physics binding us to the machines encourage us to use onomatopoeia." He distinguished, therefore, besides the already mentioned: a) direct, imitative elementary, realistic onomatopoeia, good for enriching realism with brutal reality and preventing it from becoming too abstract or too artistic (ex. pic pac pum for rifle shooting), b) indirect complex and analogical onomatopoeia, expressing the rotating noise of the African sun and the orange weight of the sky in the poem Dune, dum-dum, creating a relationship between sensations of weight, heat, colour, smell, noise, c) the abstract onomatopoeia, noisy and unconscious expression of the most complex and mysterious motions of our sensibility (ex. ran which does not express any noise of nature or of mechanism, but expresses a state of mind, d) the psychic onomatopoeic harmony, i.e. fusion of two or three abstract onomatopoeias (Marinetti, 1914). 
The sensation of movement and rhythm of the poem is also rendered by the insistence on the repetition of the same verbs of movement (the most frequent ones, together with verbs of hearing): here Miličić gives the verb a new centrality (almost one verb for every verse), preferring it to the nominal or adjectival accumulation (loved by the Decadents and Symbolists). The lyrical image of Serbia, "prelepa carska kći" (the beautiful emperor's daughter) who waits "u petvekovnoj suzi gusala javorovi" (in five centuries tears, sung by maple fiddles), seems to clash with the moving-machine beast in search for the angry dragon ("ljuti zmaj" - the Ottoman Empire), however, it does not carry the tension and the opposition (typical of the Italian Futurists) between the past and the future: the soldiers on the train are like knights in the Trojan horse ("k'o vitezovi u trojanskog konja"): the analogy therefore, another rhetorical figure dear to Miličić, links and binds, does not oppose: on the contrary, unlike Marinetti's convictions - the past does not hinder the future, but supports it instead and directs it towards a long awaited victory, already embedded in Serbian epic tradition.

In poetic language the usual associations by affinity recede into the background and appear to us more unusual and "new": while the locomotive screaming spreads out, "kliču im plodna polja" (cheer them the fertile fields, Miličić, 1914a, 13): here, moreover, the multisensory plan is called into question in the gesture of mothers ("podižu s klikom ruke") who, with a cry, raise their arms almost to bless their children, conveying lyric and plastic pathos typical of the rhetoric of war, perceived as a necessary and holy experience, according to the Serbian epic tradition, revived also in the mythopoesis of intellectuals like Miličić (and also Marinetti), who became builders of consensus on the eve of the Great War.

The world conflict saw Marinetti ${ }^{11}$ and all the Italian Futurists ${ }^{12}$ leaving for the front: even Miličić was among the first to go voluntary, in July

${ }^{11}$ In February 114, a few months before Miličić's arrival, Marinetti appeared in Russia, in Petrograd and in Moscow, also for the Futurist and war propaganda, spurring the Russians to fight against the pangermanism (De Michelis, 2009, 220).

${ }^{12}$ From the beginning of 1915 , Marinetti devoted himself completely to the propaganda for the intervention. All the Futurists, Marinetti, Russolo, Boccioni, Piatti and others joined the army as volunteers and since December1915 they fought on the front line. Boccioni will die in Sant'Elia, Russolo will be seriously injured, while Marinetti will win a second medal in the battle of Vittorio Veneto (D'Orsi, 2009, 23). 
1914. ${ }^{13}$ For Marinetti, the war represented an opportunity to transform Futurism into a political movement (D’Orsi, 2009, 68): in his propaganda article, in 1911, he was persuaded that the man of culture should have a strong public engagement and political commitment. The role of these artists, writers, musicians, appears to be central in the interventionist choice: the Great War represents for Marinetti, as for the Croat, an occasion to feed the anti-Austrian sentiment and fight the pangermanism: for Miličić, however, this involved much more, it meant extending the intents of the war to the idea of a Yugoslav union: Miličić's support for the war ideology was, therefore, also the fruit of a genuine adherence to an ideal, while for Marinetti sometimes it seemed connected, also, to the desire for protagonism (D'Orsi, 2009, 80).

Therefore, if in interventionism there are many reasons for contact between Miličić and the Futurists, right in the Great War it matures their point of rupture and "political" disagreement: the Italian imperialism and the idea of Italy as great power, of which the Futurists became the most fervent supporters, ${ }^{14}$ certainly could not have been appreciated by the Croatian: from the historical task of Italy, already outlined by D'Annunzio ${ }^{15}$ (the conquest of the whole Adriatic as a gateway to the Balkans), descended the war to Austria for the conquest of the Adriatic, ${ }^{16}$ necessary to transform Italy into an empire and into a great power (De Michelis, 1996, 162). Therefore, in August 1915 at the State Typography of the Serbian Reign

${ }^{13}$ On 12 July 1914 he worked as a teacher in Skopje: with the events of the Sarajevo attack (20 June 1914) and the Serbian mobilization (26 July 1914), Miličić was among the first to head towards Čuprija, willing to be enlisted on the front as a volunteer in the division on horseback: since he was not recruited he went to Niš, where he could join the Danube Division Headuarters (Lešić, 1991, 47).

${ }^{14}$ There was, however, some ambiguity on the part of the Italian Futurists, as Marjanović points out: in her interviews, Marinetti himself had answered evasively on the Adriatic question (Marjanović, 1911, 14).

${ }^{15}$ In the hendecasyllable tragedy The Boat (D'Annunzio, 1907).

${ }^{16}$ Araica among the political events to consider, the London Pact, signed on April 26, 1915, between Italy and the governments of the Triple Entente (Great Britain, France, Russia): in fact, with this secret Treaty, Italy betrayed the Triple Alliance of which it was part (together with Austria and Germany), and went to war against its former allies, in exchange for territorial compensation: the main lure was a promise of large swaths of Austria-Hungary in the north of Italy and to the east across the Adriatic. 
in Nis Miličićc ${ }^{17}$ hurried to publish a pamphlet entitled Dalmatian islands (Dalmatinska ostrva): the booklet, in Cyrillic ekav, was part of a series on contemporary issues with nationalistic intent, in clear opposition to the Italian policy of revanche on those places. For the same series, Miličić should have prepared other studies on Italian and Slavic culture in Dalmatia and on its economic opportunities, though never printed.

The issue of the Dalmatian islands was very serious and current: Italy, which entered the war on May $24^{\text {th }} 1915$, had spread a lot of data leading propaganda campaigns for the Italian "Adriatic," therefore, Miličić makes a detailed analysis to warn against the Italian threat. Assuming geological, historical, linguistic and demographic point of view, Miličić uses the statistical data of the Austro-Hungarian Empire, showing the Slavic great majority ("slovensku ogromnu vecinu") of those islands (Miličić, 1915, 10). But the main study is economic: with precise and sure knowledge of the history of the places he identifies the major voices of the local economy. ${ }^{18}$ The pamphlet ends with an absolute certainty: in the current war, Italy's possession of the Dalmatian islands would lead them to a sure collapse ("minovna propast") and depopulation (Miličić, 1915, 20).

But let's leave for a moment the political horizon and return to that common thread keeping his lyric united: with the third collection, the author's internal aporia is even more evident: on one hand, his activism and deep immersion in contemporary social reality and, on the other hand, the mystical, asocial, nebulous dimension expressed in his lyrics. In 1914 he published his third work, 3, a collection where Miličić abandoned the

${ }^{17}$ Set out as a volunteer for Russia in July 1915, together with other Serbian officials, he will arrive in Vladivostok and then return to Corfu (Bosković, 2006, 352-353), and leave for another troubled journey to Petrograd and Odessa from where he will come back in May 1916 (Lešić, 1991, 55-57).

${ }^{18}$ By identifying three main sources of sustenance, grapevine, fishing and oil, Miličić underlines that the Dalmatian islands could not support the Italian competitors, producing great quantity wine (Miličić, 1915, 12). As for fishing as well, Miličić analyses the current situation: there has not been any production on an industrial basis in Dalmatia, due to the lack of real industries and fast transport. Production could satisfy only for internal needs: moreover, especially for pilchards, Dalmatia suffered the competition of Chioggia's fishermen with their special nets. Even the third item of local production, oil was limited because Austria never encouraged the few Croatian entrepreneurial initiatives. That explains the beginning of emigration to America and Australia from the early twentieth century, and the islands' progressive depopulation (Miličić, 1915, 16-20). 
previous models and revealed a new sensibility and a new rhythm: while symbolism had set the free verse in motion, Futurism had instead revealed "the free words" (Milanja, 2000, 25). The new sensitivity to the Miličićan rhythm, however, is far from the free words in the Marinettian sense, as well as from its syntactic and punctuation revolution: the croatian poet is not willing to abolish even punctuation marks and, on the lexical level, unlike the Dadaists and the Zenitists, he will not reach the proto-words or archaisms of some Cosmists. The adoption of a poetic language of universal comprehension is expressed here in the repetition of "essential" names, evocative of elementary forces. And while in Marinetti there was the imperative to "abolish the adjective," Miličić, on the contrary, maintains his propension towards the latter: simple, bare adjectives, working as epithets, like in ancient religious formulas or in the myth, "iz gore strme" (from the steep mountain), "more duboko i mirno" (deep and quiet sea), "pena laka i bela" (light and white foam), "crna duboka noć" (deep and black night), "bezglasna tišina" (voiceless silence), "neznana daljina" (unknown distance), "kratki časi" (short hours), "rana teška i duboka" (hard and deep wounds), "strman breg" (steep bank), "beli galeb" (white seagull). In rhetorical figures, then, the metaphor is frequently accompanied by the analogy, perhaps an echo of the biblical and literary tradition.

The use of onomatopoeia is resumed again in some poems: in Brodić iz borove kore (The boat made of pine core), the wind, pure transcription of sounds, suitable to unhinge the lyricism of the verse, runs through the lyric as a refrain, "šš, ššš, šš." The Futurists had already appealed to the elementary language of non-linguistic primary onomatopoeias: it was the language of natural forces, expressed in a rudimentary way and more evocative and stimulating, in order to communicate and understand the elements of the universe. That's why the sound "tik-tak, tik-tak," in Knjiga Radosti, reproducing the rhythm of the universal movement ("Ritam svemira" [Universal rythm]) or that of laughter "Ha-ha-ha" ("Čista sreda" [Ash Wednesday]), is close to the futuristic onomalingua (onomalanguage), where translators are not required - as stated the futurist painter and poet Fortunato Depero (1992, 106).

The encounter with Futurism seems to leave its mark on poetry not only structurally but also thematically: here we do not see a simple variation of the poet's anxieties in the usual pessimistic-melancoholic intonation (Lešić, 
1991, 30): in the core of his poetry lies his wandering soul ("zalutala duša"), close to the "physical transcendentalism of Boccionian matrix," arising from contemplating nature through a completely modern emotion (Agnese, 1990, 222). Finally, we're approaching the conclusion with his article published on the "Srpski Književni Glasnik" (Serbian Literary Gazette I, 3/1920) where, on the basis of the many manifestos of these years, Miličić proclaims his beliefs, symptoms of a new, mature phase. The reading key we are proposing is an attempt to look at his proclamation in a clearly anti-Futurist perspective; Miličić, by now able to assert his own critical identity, affirms here his deeply anti-materialistic and anti-industrial spiritualism: ${ }^{19}$ Marinetti's fetish of technology and of the machine, the urban and progressive dynamism are now very far from his positions. The mankind can achieve not only eternity, but also true spiritual freedom thanks to poetry: poetry is, therefore, proclaimed as the new religion, free from any technical rigidity, from personal and historical selfishness ("Jedan izvod koji bi mogao da bude program" [An excerpt, that could be a program], Miličić, 1920a, 190). The idea of immanent metaphysics, present in Futurism as well, is reworked in a spiritual and not material direction: the utopia to be realized dwells upon poetry and spirit and not upon the mysticism of the Marinettian materialism, nor in his cult of the machine ${ }^{20}$ and the progress.

Miličić's position is not lonely, but, on the contrary, fits within the paradigm of the Cosmist-Expressionist scene. ${ }^{21}$ On a closer inspection, however, this new anthropology, where man takes an active part in the eternal universe by linking microcosm and macrocosm, assumes an antirationalist and anti-aesthetic attitude, probably inherited from Futurism: ${ }^{22}$

${ }^{19}$ After all, Marinetti's tendency is anti-spiritualist, exalting more the instinct than the soul: his outward and not deep attitude educes everything to a paradoxical formula in order to attract the attention of the public (De Michelis, 2009, 60).

${ }^{20}$ The modern myth of the machine, of the fast and "cinematographic" rhythm exalted by the Futurists, does not take shape in Miličić: while the Futurists write with capital letters words like Electricity, Machine, Energy, founding a sort of immanent metaphysics, the poet and painter from Brusje remains inextricably linked to words like Eternity and Mystery.

${ }^{21}$ Along with him, we find, in fact, other opponents of Expressionism such as Antun Branko Šimić and Augustin Ujević. The lyric of these years is also close to the Simfonije (1914-1919) by Miroslav Krleža (Milanja, 2008, 140).

${ }^{22}$ Miličić represents the universe as a cosmic pathos in which man, in a sort of wild and universal dance, finds the vital energy which keeps him alive: "kao što živi drvo, ptica, ne zna 
as a matter of fact, Miličić's absorbing nature, during the period of his formation, made him open to the Futurist suggestions, capable not only to receive, but also to adapt and blend atmospheres, in order to re-elaborate his own vision, seeking expressive new paths by making art and life interact constantly.

\section{References}

Agnese, G. (1990). Marinetti, una vita esplosiva. Firenze: Camunia.

Balducci, G. (2015). La spiritualità di Marinetti: fra anticlericalismo, spiritismo e cristianesimo, https://www.centrostudilaruna.it/la-spiritualita-di-marinetti-fraanticlericalismo-spiritismo-e-cristianesimo.html, 03.08.2019.

Bošković, I. (2006). Orjuna - ideologija i književnost. Zagreb: HSN.

Ćošić, B. (1931). Deset pisaca deset razgovora. Beograd: Gece Kona, pp. 47-59.

Milanja, C. (2000). Pjesništvo Hrvatskog Ekspresionizma. Zagreb: Matica Hrvatska.

De Michelis, C. (2009). L'avanguardia trasversale. Il Futurismo tra Italia e Russia. Venezia: Marsilio.

Depero, F. (1992). Pestavo anch'io sul palcoscenico dei ribelli. Antologia degli scritti letterari. Trento: Cucù libri.

D'Orsi, A. (2009). Il Futurismo tra cultura e politica. Reazione o rivoluzione. Roma: Salerno Editrice.

Juvančić, F. (1909). Manifest Futuristov. "Ljubljanski zvon” XXIX, br. 5, pp. 255-256.

Lešić, J. (1991). U traganju za nestalim pjesnikom. Sarajevo: Veselin Masleša.

Marinetti, F.T. (1909). Fondazione e manifesto del Futurismo. http://www.classicitaliani.it/futurismo/manifesti/marinetti_fondazione.htm, 12.09.2019.

Marinetti, F.T. (1912). Le monoplan du Pape. Roman politique en verses libres. Paris: Sansot. https://archive.org/details/marinetti_monoplan_1912freA, 17.08.2019.

Marinetti, F.T. (1913). Distruzione della sintassi. https://www.futurismo.org/futurismo/manifests/distruzione-sintassi/, 23.08.2019.

Marinetti, F.T. (1914). Lo splendore geometrico e meccanico (...). https://www. futurismo.org/futurismo/manifests/lo-splendore-geometrico-e-meccanico-e-lasensibilita-numerica/, 26.09.2919.

Marjanović, Z. (1911). Književna revoljta u Italiji. "Bosanska Vila” br. 13-14, pp. 209-212 .

Miličić, J. (1907). Pjesme. Wien: Hrvatsko akademsko društvo Zvonimir.

Miličić, J. (1909). Dve priče. "Letopis Matice Srpske" god. LXXXV, knj. 259, sv. VI, pp. 60-62.

sebe već za život, za večnog života: eto, to je radost" (alike the tree, the bird, it does not what is life like: so, that is life, Miličić, 1920, 5). 
Miličić, S. (1911a). Pismo iz Italije. "Bosanska Vila" br.11-12, pp. 180-181.

Miličić, S. (1911b). 10 pjesama o Don Juanu, Wien: J. Seywald.

Miličić, J. (1912). Pjesma umornog putnika, Poslje grijeha. "Bosanska Vila" br. 11-12, p. 165. https://doi.org/10.2307/2787571.

Miličić, J. (1913). Jedna Ljubav. "Srpski književni Glasnik" XXX, br. 4, pp. 241-246.

Miličić, J. (1914a). Polazak ratnika. "Bosanska Vila" br.1-6, pp. 13-14

Miličić, J. (1914b). Povratak Pobjednika. "Srpski književni Glasnik", XXXI, br. 2, pp. 193-194.

Miličić, J. (1914c). 3. Dubrovnik: Jovan Tođović.

Miličić, J. (1915). Dalmatinska Ostrva. Niš: Državna Štamparija Kraljevine Srbije.

Miličić, J. (1920a). Jedan izvod koji bi mogao da bude program. "Srpski književni Glasnik" I, br. 3, pp. 188-193.

Miličić, J. (1920b). Knjiga Radosti. Beograd: Gece Kona.

Palavestra, P. (1979). Kritika i avangarda u modernoj srpskoj književnosti. Beograd: Prosveta.

Petrač, B. (1995). Futurizam u Hrvatskoj. Zagreb: Matica Hrvatska.

Tomassucci, G., Tria, M. (red.) (2009), Gli altri futurismi. Pisa: Plus.

Trivunac, R. (1975). Na bespućima života. "Mogućnosti” 6, br. 22, pp. 692-724.

Vučković, R. (2011). Poezija srpske Avangarde. Beograd: Službeni Glasnik.

Zani, S. (1980). La mai pubblicata rivista futurista 'Zvrk' ed il futurismo in Croazia (1901-1914). "Filologia Moderna" br. 4, pp. 303-349. 